\title{
Prvi slovenski frazeološki slovar
}

\author{
Jelena Konicka
}

Cobiss: 1.02

Janez Keber, Slovar slovenskih frazemov, Ljubljana: Založba ZRC, ZRC SAZU, 2011 (Slovarji), 1158 str.

0.1 Zadnja leta 20. stoletja je zaznamoval pospešen razvoj frazeologije, kar je prineslo nova spoznanja $\mathrm{v}$ tej panogi jezikoslovja. Nova razmišljanja o frazeologiji so $\mathrm{v}$ marsičem posledica novih pristopov, ki so se uveljavili v jezikoslovju konec prejšnjega stoletja, predvsem antropocentričnega načela, ki v središče pozornosti postavlja človeka in njegovo razumevanje sveta, ki se razkriva prek izbire in oblikovanja določenih jezikovnih sredstev. Ker ta proces razumevanja sveta poteka ne le na ravni logičnega mišljenja, ampak precej čustveno, so se raziskave ekspresivnih jezikovnih sredstev (med njimi frazemov) premaknile v ospredje zanimanja jezikoslovcev. V zvezi z razumevanjem frazemov kot rezultata konceptualizacije, ki izvira iz našega splošnega védenja o svetu, je na novo zaživela kontrastivna primerjava frazeoloških sestavov različnih jezikov kot odseva nacionalno-idiomatičnega dojemanja sveta. Emotivnost, pragmatičnost, nominativni potencial frazemov, njihova simbolna vloga, kulturološki pomen, določanje frazemskih mej in obsega frazeologije v celoti so vprašanja, ki so danes aktualna za jezikoslovce na Slovenskem in v drugih slovanskih in neslovanskih deželah.

0.2 Za verodostojne in utemeljene odgovore na zastavljena vprašanja so nujno potrebni kompetentni viri, pripravljeni z upoštevanjem sodobnih znanstvenih metod in spoznanj, predvsem frazeološki slovarji. O povečanem povpraševanju po sodobnih frazeoloških slovarjih v slovanskem svetu priča izid številnih leksikografskih del, ki so se pojavila zadnja desetletja; tako je npr. na Poljskem od začetka 21. stoletja izšlo kar 18 frazeoloških zbirk (tudi v ponatisu), ${ }^{1}$ v Rusiji nekaj manj del,

1 Naj navedem nekatere izmed njih: W. Rzehak - M. Paw - M. Wawrzecki, Stownik zwiqzków frazeologicznych (2012); P. Fliciński, Stownik frazeologiczny (2012); M. Czeszewski K. Foremniak, Ludzie i miejsca w języku: stownik frazeologizmów eponimicznych (2011); A. Kłosińska, Stownik frazeologiczny PWN z płyta CD (2011); M. Dobrowolski, Słownik frazeologiczny (2010); J. Liberek - S. Bąba, Popularny stownik frazeologiczny (2010), E. Dereń - T. Nowak - E. Polański, Stownik języka polskiego z frazeologizmami i przystowiami (2009); R. Lebda, Wielki słownik frazeologiczny (2008), K. Głowińska, Stownik frazeologiczny (2008); E. Sobol (zasnova), Stownik frazeologiczny PWN z Bralczykiem (2008); T. Mrozowski, Stownik frazeologiczny polsko-niemiecki = Phraseologisches Wörterbuch PolnischDeutsch (2007); Stownik zwiqzków frazeologicznych (skupinsko delo, 2004); J. Liberek - S. Bąba, Mały stownik frazeologiczny wspótczesnego języka polskiego (2003) idr. 
ki pa so zelo pomembna za rusko frazeologijo in frazeografijo del, kot npr. Bol'šoj frazeologičeskij slovar' russkogo jazyka (BFSRJ).

Pripravljanje slovarja je velikansko delo, ki zahteva izdelavo znanstvene zasnove in njeno dosledno izvedbo. Glede na število slovarjev, nastalih v slovanskem svetu pred kratkim, imamo danes na razpolago različne zasnove frazeoloških slovarjev: razlagalnih, etimoloških, kulturoloških, namenjenih dijakom, sopomenk in protipomenk, večjezičnih idr.

- $\quad 0.3$ Povedano o slovarjih na Poljskem ali v Rusiji se ne da primerjati s stanjem na Slovenskem, kjer je bil do pred kratkim edini zanesljivi vir za frazeologijo Slovar sodobnega slovenskega knjižnega jezika (SSKJ), ki znanstvenim načelom ustreza le delno (gl. Peterman 1988; Kržišnik 1987/88). Drugo slovensko gradivo se je iskalo po zbirkah brez znanstvene zasnove, kot so npr. petjezični frazeološki slovar Josipa Pavlice (1960), zbirka pregovorov in rekov Etbina Bojca (1974, 1980, 1987) idr.

1.0 Leta 2011 je izšel Slovar slovenskih frazemov (SSF) Janeza Kebra, prvo obsežno slovensko frazeografsko delo. Tovrstni slovar so težko čakali v Sloveniji, tuji raziskovalci slovenščine in tisti, ki se ukvarjajo s primerjalnim in kontrastivnim jezikoslovjem. Slovensko gradivo je dragocen pripomoček pri raziskovanju slovanske frazeologije, splošnih frazeoloških modelov, razvoja frazemskega pomena, krčenja frazemov, pri določanju splošnega in nacionalno specifičnega, da ne govorimo o praktični potrebi po frazeološkem slovarju za Slovence, ki si želijo več vedeti o maternem jeziku, pa tudi za tujce, ki bi se radi naučili slovenščine.

1.1 Erika Kržišnik v svoji oceni Poskusnega zvezka Frazeološkega slovarja Janeza Kebra (FSSJ PS) poudarja, da je njegov izid »hvalevredna poteza Leksikološke sekcije pri Inštitutu za slovenski jezik Frana Ramovša ZRC SAZU « (Kržišnik 2004: 199). Isto velja za SSF. V njem je veliko zanimivega, kar odseva samosvoj pogled Slovencev na svet; to razkrivajo npr. frazemi platno prodajati 'biti še majhen otrok', trda prede 'težko živi, je v neprijetnem položaju', vsi križi so dol 'vse je zelo narobe', zbit kot turška fana 'zelo izmučen', leto in dan 'zelo dolgo' ali celo biblični frazemi, npr. gledati kakor levi razbojnik 'gledati mrko, hudobno', česar v drugih slovanskih jezikih nimamo. Zanimivi so frazemi matilda je pobrala koga 'kdo je umrl' ali pa [lepo] po vrsti, kakor [so] hiše v Trsti 'izraža pravilno, normalno zaporedje česa', prosto po Prešernu 'poljubno, brez načrta, prepuščajoč se trenutku', ob svetem Nikoli 'nikdar' idr., ki imajo izrazit slovenski pridih. Nove razsežnosti za slovansko frazeologijo odpirajo frazemi kot npr. živeti na koruzi (z navedenim v SSF prim. ukr. skakaty v grečku), slikati vraga bolj črnega, kot je $v$ resnici 'imeti kaj za bolj negativno, kot je v resnici' (prim. rus. pregovor ne tak strašen čërt, kak jego maljujut); tudi biblični frazemi v slovenščini lahko imajo malo drugačen pomen ali se drugače uporabljajo kot npr. v ruščini, prim. slov. Noetova barka s pomenom 'pribežališče, zatočišče', medtem ko rus. Noev kovčeg pomeni 'prostor, prenapolnjen z ljudmi' (iron.) (FSRLJ), redko, knj. 'reševalno sredstvo' (rus. sredstvo spasenija, BSRP); frazem iz Savla postati Pavel se uporablja v knjižni slovenščini, v ruščini pa se uporablja ustrezni frazem knj., iron. prevraščenije Savla v Pavla (KSBF). 
2.1 Slovar slovenskih frazemov je sestavljen iz Uvoda, ki vsebuje Predgovor (str. 7-13), Vire in Slovensko in neslovensko literaturo (str. 13-26), Seznam kratic in okrajšav (str. 27), Napotke in pojasnila (str. 29-30) ter nazorno Predstavitev zgradbe geselskega članka (str. 31), in Slovarja (str. 33-1158). Iz uvoda bralec spozna (poleg nadrobne razlage avtorjevih razmer za delo na SAZU-ju in objavljenih del) avtorjevo razumevanje frazeologije in načel razporeditve frazeološkega gradiva $v$ slovarju ter načel obdelave frazemov. ${ }^{2}$

2.2 V predgovoru Keber opozarja, da SSF vsebuje frazeme v ožjem pomenu, tj. ne vključuje terminoloških besednih zvez, rekov, pregovorov in krilatic, čeprav je nekaj takih enot prišlo v SSF, »ker je tako narekovala njihova aktualna frazeološka raba« (str. 9); žal avtor povedanega ni razložil. V SSF so se poleg frazemov znašli pregovori, reki in krilatice, kot npr. veliko babic - kilav otrok/kilavo dete, mi o vol$k u$, volk iz gozda, nekaj gnilega je v deželi Danski itd., tudi naslovi organizacij, npr. Rdeči križ, terminološke zveze, npr. kozje molitvice (gl. zgled v SSF: »Na zgoščenki je štirideset zapisov, poleg pesmi tudi reki, zagovori, fantovske ,kozje molitvice“«), imena praznikov, npr. prvi maj, velika noč itd., ne najdemo pa znanih slovenskih frazemov, kot npr. pustiti času čas, metati denar v zrak, graditi na pesku, tik pred zdajci, od šuba idr. Ni jasno, zakaj je avtor uvrstil med frazeme tudi besedne zveze, ki imajo neposredni pomen, kot npr. nacionalna katastrofa.

2.3 V SSF so enote razporejene po abecednem in slovničnem načelu, vsaka je opremljena z naglasi, kar je zelo pomembno. Janez Keber loči glavno iztočnico, pri kateri navaja sedem sestavin: (1) frazem v izhodiščni slovarski obliki; (2) zvrstne, stilne in druge oznake; (3) slovnične in druge oznake; (4) razlago ali več razlag; dodane so lahko tudi sopomenke, protipomenke, pomensko ali predstavno enaki ali sorodni frazemi ali enobesedni izrazi; (5) ponazoritev z besednimi oblikami v zgledih z upoštevanjem starejših slovarjev in narečne kartoteke; (6) podatek o nastanku, izvoru, motivu nastanka frazema (fakultativno); (7) primerjava z ustreznimi frazemi v nekaterih drugih jezikih (fakultativno) (str. 10-12). Druge iztočnice so neglavne, običajno so opremljene z zgledi, pri njih ni razlag, imajo pa kazalko na glavno iztočnico. Sistem kazalk je precej zapleten, npr. pri geslu ločitev od mize in postelje z oznakama pravn., ${ }^{3}$ pren., razlago pomena 'zakonska zveza, v kateri zakonca ne živita $\mathrm{v}$ zakonski skupnosti', ponazoritvenimi zgledi in francosko ustreznico najdemo kazalko na ločen od mize in postelje brez obravnave, od tod pa na miza, kjer se dobi frazem ločen od mize in postelje z oznakama ekspr., pren. in navedenim pomenom 'biti v zvezi, a ne sodelovati'; 4 še en zgled verižnih napotkov: znajti se na tankem ledu s kazalko na biti na tankem ledu, pri kateri je kazalka na led.

2.4 Včasih je težko presoditi, ali je iztočnica glavna ali neglavna, prim. iztočnice tresti se kakor trepetlika [v vetru] in tresti se kot trepetlika; presegati vse meje in to

2 SSF je zelo dobro predstavljen v oceni J. Rojsa (2012).

3 Frazem ima oznako pravn. (najbrž zaradi nastanka), vendar pa ni iz sodobne pravniške terminologije, zato je ta oznaka odveč.

4 Pri tem si neizkušeni bralec seveda zastavlja vprašanje, zakaj so pri enoti, ki vsebuje glagolnik, navedene oznake, ki niso usklajene z oznakami pri enoti z deležnikom, in zakaj je prišlo do spremembe pomena. Izkušeni bralec tega najbrž prav tako ne bo znal razložiti. 
presega vse meje: v obeh parih sta članka oblikovana enako. Podobna sta si članka poskusni zajček in poskusni zajec, ki vsebujeta vsa merila. O tem, da sta zadnji dve enoti med sabo povezani, pove opozorilo na začetku prvega članka, kjer bralec izve, da ima frazem sopomenko poskusni zajec, na koncu pa prebere, da je frazem poskusni zajec »redkejša različica«.

3.1 Pri sestavljanju frazeološkega slovarja se mora avtor odločiti, kaj so frazeološke različice in kaj sopomenke, ker je od tega odvisno uvrščanje frazemov ali v glavne ali pa v neglavne iztočnice. Če je enota določena kot sopomenka, jo je treba navajati kot glavno iztočnico, če kot različica, pa jo je logično uvrščati kot neglavno. V SSF avtor ne loči teh dveh vrst enot.

3.2 Ruska frazeologija (in frazeografija) razume variantnost frazemov kot spreminjanje oblike frazema na različnih ravneh v okviru iste skladenjske konstrukcije brez spremembe semantične enakosti frazema. Ruski frazeologi najpogosteje naštevajo šest vrst frazeoloških različic, in sicer (1) glasoslovne ali pravopisne, (2) morfološke (paradigmatske), (3) konstrukcijske (enote s krnitvijo ali dodajanjem komponent), (4) skladenjske, (5) leksikalne, (6) besedotvorne (Mokijenko 1989: 11), V. P. Žukov navaja še vidske različice, konstrukcijske in skladenjske pa obravnava skupaj (Žukov 1978: 165); nekateri frazeologi se omejujejo na pet vrst različic, in sicer komponentne, oblikoslovne, grafične, leksikalne, mešane (Vostrecova 2009: 39). Največ se diskutira o interpretaciji leksikalnih sprememb, npr. verige rus. lizat' pjatki, lizat'nogi in lizat'sapogi, tudi viljat'hvostom in vertet'hvostom V. P. Žukov interpretira kot frazemske različice (SFSRJ), A. I. Fjodorov, ki prišteva k različicam samo frazeme $\mathrm{z}$ glasoslovnim in oblikoslovnim speminjanjem komponent frazema (Fjodorov 1973: 20), pa razlaga podobne enote kot sopomenske (FSRLJ 1997). V. M. Mokijenko zagovarja stališče, da je treba frazeološke verige razumeti kot različice, če se v njih ne spremenijo frazemski pomen, konotacije, skladenjska konstrukcija in se ohrani slika (rus. obraz), tj. značaj frazema (Mokijenko 1989: 30), čeprav pride do leksikalnih sprememb.

3.3 V SSF so zastopane slovenske frazeološke različice vseh vrst: pravopisne, oblikoslovne, leksikalne in komponentne. Dovolj dosledno so predstavljene pravopisne različice, npr. Ahilova (ahilova) peta, Sizifovo (sizifovo) delo, prestopiti Rubikon (rubikon) idr., čeprav take različice niso navedene pri vseh frazemih, npr. poleg frazema Avgijev hlev ni grafične različice avgijev hlev (gl. v korpusu NB: »Slovenska institucionalna kinematografija se je v prvem desetletju obstoja filmskega sklada spremenila v avgijev hlev«; »,Računovodje družbe Price Waterhouse \& Cooper se morajo v Hypu počutiti kot v avgijevem hlevu, ' piše koroški Kleine Zeitung«), enako Lahov koš (tudi lahov, NB: »Kaj bo Janez s Katro, ki je revna kakor lahov koš? «), Tantalove muke (tudi tantalove, NB: »Čeprav na zunaj ni videti, pa prave povolilne tantalove muke preživljajo Boris Tadić in njegovi koalicijski partnerji $\ll)$ idr.

3.4 Na možne morfološke različice, povezane s številom in z vidom, v SSF opozarjajo oznake v glavnem geselskem članku; poleg tega so frazemske različice navedene v posebej predstavljenih neglavnih člankih. 
3.4.1 V SSF nimajo vsi frazemi oznake za možne spremembe števila, npr. pri frazemih Avgijev hlev, volk v ovčji koži idr. ni oznak za možnost množinske različice, čeprav jo zgledi iz korpusov potrjujejo: »Namesto da bi izkoristila neuradno zapovedanih 100 dni ,pax romana za mirno programiranje dela v prihodnosti, se je lotila čiščenja Avgijevih hlevov svojih predhodnikov« (NB), »Tudi v Pakistanu so islamski Avgijevi hlevi, ki jih bodo tisti v Afganistanu želeli urejati«; »Sama je doslej živela v varnem družinskem okolju in ni poznala moških ,volkov v ovčji koži “" (GF). Pri oznakah za možnost množinske ali edninske različice je avtor SSF včasih nedosleden; tako je npr. pri enoti do skrajne meje navedena možnost množinske različice, pri enoti do skrajnih mej $j^{5}$ pa ni opozorila na možnost edninske.

3.4.2 Navajanje oblikoslovnih različic $z$ dovršno/nedovršno obliko je podobno prej omenjenemu. Tudi tu najdemo nedoslednosti, npr. pri frazemu zvrniti kozarec Keber opozarja na nedovršno obliko zvračati, pri enoti zvrniti kozarček pa take opombe ni, čeprav je nedovršna oblika v rabi: „Če preveč zvvračamo kozarčke, se ga bomo nažokali«, »Glasno se pogovarjajo in smejijo ter zvračajo kozarčke portovca in sherryja (GF); enako je pri izvleči koga/kaj iz blata opozorjeno na možnost nedov. vleči, medtem ko pri izvleči se iz blata nedovršnik ni naveden, v NB pa najdemo primer: »To se po nekaj letih političnega miru in razumnega županovanja Antona Slane tudi opazi, občina se počasi vleče iz blata odmaknjenosti in nerazvitosti.«

4.1 Konstrukcijske različice so v SSF načeloma označene s fakultativnimi sestavinami, navedenimi v oglatem oklepaju, npr. kakor amen [v očenašu], čeprav niso vsi frazemi, ki imajo fakultativne sestavine, opremljeni na tak način. Npr. dvigniti se kot feniks iz pepela s pomenom 'preroditi se, pojaviti se, priti kot nov, v vsej moči' (str. 200) in dvigniti se kot ptič feniks iz pepela (str. 777) 'isto' sta določeni kot sopomenki; posebej sta navedeni različici vsake bire in vsake bire in baže s pomenom 'vsake vrste, vseh vrst'. V nekaterih primerih avtor vidi pomensko razliko med različicami take vrste, npr. sesuti koga/kaj v prah 'uničiti koga, porušiti kaj' in sesuti koga/kaj v prah in pepel 'popolnoma uničiti koga, kaj'; enako enoti sesuti se v prah: 1. 'zdrobiti se, razpasti'; 2. 'biti porušen, uničen' in sesuti se v prah in pepel 1. 'popolnoma porušiti se'; 2. 'propasti, biti popolnoma uničen', čeprav, kot se zdi (in kažejo zgledi), imata obe enoti isti pomen. Druge vrste odnose so v paru križ je [s kom/čim] in velik križ je s kom/čim (grafične razlike v paru glede fakultativnosti sestavin so iz SSF), kjer je pomen frazema okrepljen s pomočjo pridevnika.

4.2 Vprašljivo v SSF je navajanje različic s pomožnimi glagoli in povedkovniških frazemov. Ob tem je treba opozoriti, da so take različice v podobnih primerih opremljene različno, npr. pri enoti biti na pragu življenja je kazalka na različico na pragu življenja, enota biti na pragu smrti (s tiskovno napako: bitina pragu) pa je brez kazalke na različico na pragu smrti (ki je ni v SSF, čeprav je različica v rabi:

5 V slovenskih korpusih (GF, NB) ima največ zadetkov oblika frazema do skrajnih meja, ki ni navedena v SSF niti kot različica niti med primeri. V NB je razvrstitev različic taka: do skrajne meje - 39 zadetkov, do skrajnih mej - 9, do skrajnih meja - 181. 
»Predrzne so misli na pragu sanj, predrzne kakor na pragu smrti« (NB), »Njegova podoba je postala spet problematična z industrializacijo 19. stoletja, ko oddaljeni oče na pragu smrti ni več deloval v družbi« (GF). Različice brez glagola in z glagolskim okoljem ${ }^{6}$ niso na vseh mestih povezane med sabo in se navajajo včasih brez napotkov, npr. vitka linija 'vitko telo, vitka postava, vitkost' in ohraniti vitko linijo 'ohraniti vitko telo, postavo'. Pričakovati bi bilo vsaj doslednost pri izbranem načelu obravnave.

5.1 Leksikalne različice so take, ki vsebujejo lekseme iste pomenske skupine, med njimi tudi sopomenke (Mokijenko 1989: 31-34), zato so enote, kot npr. iskati iglo $v$ senu in iskati šivanko $v$ senu ali biti med krilatci [božjimi] in biti med angelčki, spati kot angel in spati kot angelček, v katerih ne prihaja do spremembe pomena, konstrukcije in konotacij, frazemske različice. V SSF take enote nimajo splošne definicije; včasih so določene kot sopomenke, včasih pa kot različice, npr. pri enoti luč na koncu predora je v oznakah navedeno: »tudi tunela«, kar naj bi pomenilo opozorilo na frazemsko različico (z drugim leksemom); pri enoti luč na koncu tunela pa je navedeno, da ima frazem sopomenko luč na koncu predora. Težje je najti odgovor na vprašanje variantnosti frazemov s spremenjeno glagolsko sestavino, vendar se zdi večkratno navajanje frazemov z različnimi glagoli v posameznih člankih nekoristno, npr. pet minut [slave] se navaja z glagoli čakati, dočakati, doživeti, imeti, izkoristiti, izrabiti.

6.1 Navajanje leksikalnih in konstrukcijskih različic na več mestih v slovarju prinaša precej težav pri njegovi uporabi; manj zapletena se zdi uvrstitev različic v enem geselskem članku z grafičnim (tiskovnim) označevanjem leksemskih različic in navajanjem ponazarjalnega gradiva pri različicah, kar bi ustrezalo praktičnim nalogam slovarja in tudi teoretskim frazeografskim načelom, ki so sprejeta v različnih nacionalnih frazeografijah.

7.1 SSF prinaša veliko zanimivega gradiva s področja frazemske sopomenskosti. Po splošno sprejeti definiciji imajo sopomenke (skoraj) enak pomen in se uporabljajo v podobnih kontekstih; v besedilu jih lahko zamenjamo, ne da bi se pri tem spremenil pomen, npr. ta je [pa] bosa, izpod pazduhe vzet, ta je [pa] kosmata, ta je [pa] jalova; otrobe vezati, mlatiti prazno slamo ipd. Vendar enote rdeč kot kuhan rak, rdeč kot kri, rdeč kot makov cvet, rdeč kot puran, ki jih Keber navaja kot sopomenke, niso sopomenske, ker se frazema rdeč kot puran in rdeč kot kuhan rak nanašata na človeka, torej se vežeta na živo, medtem ko se frazem rdeč kot kri (sodeč po ponazarjalnih primerih, navedenih v SSF) veže predvsem na neživo: $t l a$, vino, rubine, zvezde ipd. ${ }^{7}$ takih enot $\mathrm{v}$ besedilu ne moremo zamenjati.

6 Seveda, če jih sploh razumemo kot različice, kar je zelo vprašljivo, gl. Kržišnik 2004.

7 Včasih se nanaša frazem tudi na živo, npr.: »Črne kot noč, rdeče kot kri in bele kot sneg so bile kot novodobne Sneguljčice« (GF). 
8.1 Frazemi so v SSF opremljeni s stilnimi, zvrstnimi in drugimi oznakami. »Navajanje oznak pomeni, da bo slovenski frazeološki slovar normativen« (str. 11), zato predvidevamo dosledno in upravičeno pripisovanje oznak frazemskim enotam, medtem ko je za SSF pri tem značilna nedoslednost. Npr. pri frazemu ne ozirati se ne na levo ne na desno so navedene oznake ekspr., tudi pren., dov. ozreti; naslednja enota (ki je pomensko, skladenjsko in predstavno enaka omenjeni) ne pogledati ne na levo ne na desno ima drugačno verigo oznak: ekspr., nikal., predl. zv. Katere oznake so pravilne in ali sta obe verigi pravilni, je težko ugotoviti, ker oznake v SSF niso razložene: avtor se je pri oznakah večinoma zgledoval po SSKJ, v predgovoru pa poudarja, »da so te izbrane po avtorskem individualnem občutku, ki se je izoblikoval $\mathrm{v}$ dolgoletnem intenzivnem slovarskem delu $\mathrm{z}$ gradivom najrazličnejših slogov« (str. 11).

8.2 Uvajanje oznak brez dodatnih pojasnil in nedoslednost pri označevanju stilskih in oblikovnih posebnosti frazemov spravlja $\mathrm{v}$ nekaterih primerih bralca $\mathrm{v}$ zadrego, namesto da bi mu pomagala. Rečeno velja med drugim za oznako ekspr., ki je pripisana npr. pri frazemih rasti kot gobe po dežju, imeti hudiča v sebi, metati komu pesek v oči, medtem ko pri npr. malati hudiča na steno, biti brez sape take oznake ni. Pogoji za oznako pren. niso določeni, zato ni jasno, zakaj ima dobiti jih po gobcu ima oznako nizko; pren., po drugi strani pa ima dobiti eno na gobec pripisano nizko, olepš. in ne pren. Frazem za vraga [svetega] je opremljen z oznakami pog., ekspr., olepšs, čeprav se oznaka olepš. najbrž nanaša le na različico s fakultativno sestavino, dano v iztočnici v oklepaju. Včasih namesto sodobne zvrstne oznake avtor navaja diahrono (po izvoru frazema), npr. frazem ločitev od mize in postelje je opremljen z oznako pravn. Nedoslednost se da najti pri oznaki bibl., ki je navedena pri frazemih metati bisere svinjam in biti sol zemlje, medtem ko so enote sedem debelih krav, sedem suhih krav, volk $v$ ovčji koži, prepovedan sad idr. brez nje. Tudi s časovnimi oznakami ni vse rešeno, npr. pri frazemu brati med vrstami so navedeni zgledi iz slovenskega slovstva iz 19. in začetka 20. stoletja (avtor najmlajšega citata, iz leta 1938, je G. Šilih (druga dva citata sta iz I. Cankarja in J. Jurčiča), zato bi lahko pričakovali v SSF oznako star., ki je ni; to velja tudi za različico tresti se kakor trepetlika [v vetru], za katero Keber navaja le zglede iz slovenskega slovstva 19. stoletja, in sicer Janka Kersnika in Ivana Tavčarja (v GF ni niti enega zadetka). Po drugi strani je frazem hoditi od Poncija do Pilata opremljen z oznako star., čeprav je v aktivni rabi (število zadetkov v GF: 74 iz časopisja, 17 iz revij, $9 \mathrm{z}$ interneta). Slovnični podatki so prav tako navedeni nedosledno, npr. frazem kri je izginila komu z lic ima oznako 3. os. ed., medtem ko kri je šla v glavo komu take oznake nima. Naštevanje nedoslednosti bi lahko nadaljevala $\mathrm{z}$ oznakami različnih vrst.

9.1 Eden najpomembnejših ciljev frazeološkega slovarja je določitev frazeološkega pomena, kar je včasih težka naloga. Čeprav je SSF namenjen predvsem Slovencem, je dragocen tudi za tujce, ki se zanimajo za slovenščino, in za tuje raziskovalce slovenščine. Rojeni govorci vsaj intuitivno lahko razumejo slovenske frazeme, za tujce pa je ta naloga precej zahtevna, še posebej, če gre za internacionalizme ali za frazeme skupnega indoevropskega ali slovanskega porekla, kjer lahko pride do pomenskih sprememb. Eno takih kaže npr. frazem kaj je [kot] bob ob 
steno s pomenom 'kaj je brez uspeha, zaman', ker ima njegova ustreznica v drugih slovanskih jezikih malo drugačno razlago, prim. rus. goroh ob stenku: 'ne vozdejstvujet, ne okazyvajet nikakogo vlijanija na kogo-libo (čto-to skazannoe)' (FSRLJ), polj. groch o ściane ‘daremnie przekonywać, pouczać, upominać kogo' (Skorupka 1967: I, 262), slovaško hádzat' (sypat') hrach na stenu 'márne, nadarmo, bezvýsledne, zbytočne hovorit' niečo; naimá napominat' nevšímavého človeka' (Smiešková 1983: 76). Analiza slovenskega ponazarjalnega gradiva kaže, da se frazem uporablja v pomenu, navedenem v SSF, vendar pogosto ob leksemih s pomenom komuniciranja (govorjenja): priporočila, prošnje, besede, zahteve, ugovori idr., torej vsebuje še dodatno pomensko sestavino. ${ }^{8}$ Slovenski frazem je ohranil (v določenih kontekstih) prvotni pomen, obenem pa ga je razširil.

9.2 Frazeologi soglašajo, da je frazeološki pomen nemogoče izpeljati ali pa ga je deloma mogoče izpeljati iz pomena sestavin frazema; pomen, ki ga iščemo v slovarju, ni enak neposrednemu pomenu homonimne besedne zveze, ki ni uvrščen v frazeološki slovar v vlogi pomenske definicije. V SSF je v nekaterih primerih prišlo do zamenjave frazemskega pomena z neposrednim, npr. enota Matjaževa brada ima razlago 'brada pravljičnega kralja Matjaža', kar predstavlja neposredni pomen besedne zveze; v slovenščini obstaja tudi frazem Matjaževa brada (poleg variantne oblike brada kralja Matjaža), npr.: »... če bi bili preštudirali vse tisto, kar bi bilo po mojih mislih treba preštudirati takim glasnim vsevedcem, bi moral imeti vsakdo izmed njih Matjaževo brado« (NB); »Načrt, ki ima ,brado kralja Matjaža', je šele na polovici« (GF); »Prej boš imel brado kralja Matjaža kot pahljačaste liste« (najdi.si). Iz zgledov je možno določiti dva frazeološka pomena: 1. 'zelo dolg'; 2. 'ki traja dolgo časa'. ${ }^{9}$ Presojanje pomena frazemov, ki imajo homonimno prosto besedno zvezo, zahteva posebej veliko pozornosti, kar se vidi tudi pri frazemu ne ozirati se ne na levo ne na desno, ki ima kot prvi pomen navedeno 'iti naravnost, brez oziranja' (str. 467), ${ }^{10}$ ta pomen pa ne spada $\mathrm{v}$ frazeološki slovar.

9.3 Slovarska definicija pomena v slovarju mora vsebovati vse pomenske sestavine frazema, kar je pomembno za rabo in pravilno razumevanje frazeoloških enot. V SSF je včasih treba sestavljati pomen iz članka v celoti. Npr. frazem kri teče kje ima razlago 'ugašajo življenja' brez sestavine 'v vojni ipd.', o čimer piše avtor na koncu članka; kot pomembno pomensko sestavino bi to bilo treba navesti že v razlagi pomena. Pomanjkljivosti pri opisu pomena frazema se da najti na več mestih; npr. pomen enote kurja polt spreleti koga je določen kot 'kdo dobi navadno zaradi mraza ali groze naježeno kožo', čeprav se ta frazem uporablja, ko govorimo o

8 O tem med drugim pričajo sopomenke sorodnega frazema bob ob steno metati, navedene v SSF (s pomenom 'opravljati nekoristno delo, zaman se truditi'), in sicer $v$ rešetu vodo nositi 'zaman tratiti čas, zaman se truditi, neumno ravnati'; polniti sod brez dna 'opravljati nekoristno, nikoli končano delo'; $v$ veter, $v$ burjo govoriti 'govoriti v prazno, zaman'.

9 Zaradi nepravilnega določanja pomena je enota Matjaževa brada v SSF opremljena z oznako nevtr. namesto ekspr.

${ }^{10}$ Mimogrede opozarjam na to, da je napačna tudi ta razlaga pomena besedne zveze, ker vsebuje glagol iti, medtem ko je iz navedenih zgledov razvidno, da ne gre le za hojo, npr: $»$ Vozil je hlode iz gozda ali sekal leščevje v gmajni. Pri tem ni videl ne na levo ne na desno.« 
močnem vznemirjenju sploh, npr. »Toda človek doživlja glasbo na samosvoj način: veliki krešendo ga lahko gane do solz, oblije ga kurja polt, množico na kakšnem shodu povzpne do nebes« (GF).

9.4 Preobsežne definicije so v slovarju tudi napačne, npr. pomen zakon džungle v SSF je naveden kot 'brezpravje, nered; pravica močnejšega', zgledi pa kažejo, da je aktualen le zadnji del dane razlage ('pravica močnejšega'); gl. tudi razlage pri držati ogledalo koти/čemu, kazati ogledalo koти/čemu in nastaviti ogledalo komu/čemu, ki imajo enak pomen 'kritično ocenjevati koga, kaj, opozarjati na napake', vendar je razlaga prve enote razširjena $\mathrm{z}$ ' $\mathrm{v}$ umetniških, zlasti gledaliških delih prikazovati problematiko določene dobe'.

9.5 Vsebina slovarskega članka ne sme vsebovati nasprotujočih si trditev, čemur se avtor pri sestavljanju SSF ni izognil. Npr. frazem kurja polt ima razlago 'groza', v nadaljevanju članka pa bralec izve: "poimenovanje kurja polt, narečno tudi kurja koža, se uporablja v pomenu 'zaradi mraza ali groze naježena koža'« (str. 725); enako dlani srbijo koga z oznakami pog., olepš., ${ }^{11}$ mn., kot grožnja sobesedniku, dov. zasrbeti, potem pa razlaga frazemski pomen: 1. 'ima željo, čuti potrebo, da bi udaril'; 2. 'nestrpno čakati na kakšno delo'.

Druge vrste nasprotujoči si podatki so v članku o frazemu beseda je meso postala (s pomenom 'kar je bilo govorjeno, se je uresničilo'), ki ga J. Keber primerja $\mathrm{z}$ mi o volku, volk iz gozda, v razlagi frazema beseda je meso postala pa pove, da ta »ponazarja vzklik, ki spremlja nepričakovano pojavitev koga ali česa, o komer ali čemer se pravkar govori« (str. 65); enako pri enoti mi o volku, volk iz gozda najdemo: »prim. beseda je meso postala « (str. 1050), medtem ko zgledi rabe nič ne kažejo na primerljivost teh dveh enot, prim. v SSF: »No, mogoče pa mu delamo krivico, saj včasih pokaže že naravnost junaško zavzetost, da bi udejanil kako odločbo sodišča in da bi beseda pravice vendarle meso postala; ... ker je bilo podobne napovedi slišati že večkrat, beseda pa še vedno ni meso postala."

9.6 V SSF je izpeljano razčlenjevanje pomenov večpomenskih frazemov, npr. dihati komu za ovratnik: 1. 'zelo se približevati komu; tesno slediti komu'; 2. 'nadzorovati, preganjati koga' idr. Včasih pa sta navedena dva različna pomena skupaj, npr. pomen frazema kot v peklu v SSF je določen kot 'zelo vroče; zelo hudo'; prvi navedeni zgled (»Po fantovskem pripovedovanju so v njegovi družini živeli huje kot v peklu«, namreč zaradi očetovega pijančevanja) potrjuje pomen 'zelo hudo', ne potrjuje pa pomena 'zelo vroče', ki ga izkazuje drugi zgled (»Na ulicah Istambula ... je bilo po zmagoslavju nogometašev Galatasaraya kot v peklu«). ${ }^{12}$ Podobno sta pri frazemu figov list navedena dva pomena: 1. 'na umetniški upodobitvi nagega človeškega telesa stiliziran figov list, ki pokriva osramje; kopalno oblačilo ali njegov del, praviloma žensko, ki samo delno ali slabo zakriva goloto'; 2. 'kar prikriva

11 Vprašljivo je navajanje oznake olepš. (= olepševalno).

${ }^{12}$ Treba je tudi opozoriti, da ima frazem še tretji pomen, 'zelo glasno', ki ga je možno določiti po gradivu v korpusu NB: »Ropotalo je kot v peklu«, »Za nekaj trenutkov je nastala tišina, potem pa so se pričela tresti tla in bobnelo je kot v peklu« (NB), »Pokalo je kot v peklu«. 
pravo dejavnost, bistvo stvari'; vendar sta pod točko 1 predstavljena dva različna pomena. ${ }^{13}$ Vse pomene bi bilo treba navesti ločeno.

9.7 Nedopustno se zdi navajanje nepravilnega pomena. Tovrstne napake so v SSF sicer redke, npr. pomen frazema oprati komu možgane je 'zelo ošteti koga', kot sopomenka je naveden frazem oprati komu glavo. Vzporednice slovenskega oprati komu možgane so v rabi v različnih jezikih, npr. rus. promyvat'mozgi s pomenom 'vozdejstvovat' na psihiku čeloveka s celju ego ideologičeskoj obrabotki; dolgimi ugovorami, uveščevanijami zastavljat' kogo-l. prinjat' svoju točku zrenija' (SRF: 383), polj. pranie mózgu 'opaczne kształtowanie czyjichś poglądów, czyjegoś systemu wartości za pomocą silnej presji psychicznej, indoktrynacji; dezorientowanie kogoś, manipulowanie kimś' (SF). Gradivo potrjuje pomensko sorodnost slovenskega frazema z navedenimi tujejezičnimi frazemi, prim.: »Vsi se imajo za mučenike. Pogosto jim ,operejo možgane‘. V dolgih urah in dnevih ideološkega pranja možganov jim obljubijo muslimanski raj ali obet, da bodo pozneje dobili častno mesto med nacionalnimi junaki.«

10.1 Za določanje frazemskega pomena je zelo pomembno ponazarjalno gradivo, ki pojasnjuje navedene pomene, obenem pa prinaša védenje o sintagmatiki frazemov. V SSF ponazarjalno gradivo prikazuje aktualno rabo frazema in rabo v preteklosti, kar je seveda zelo poučno. Žal pa so včasih zgledi premalo informativni, npr. pri frazemu imeti vraga v sebi (s pomenoma 1. 'doseči kaj navidez nemogočega; biti ne kar tako'; 2. 'biti zelo hudoben') je prvi pomen opremljen z zgledom »Jaz sem tvoja sestra in imam menda istega vraga v sebi kakor ti «, ki je lahko zgled za drugi pomen; prim. tudi zgled »Saj vem, da mečem bob ob steno«, ki ponazarja frazem bob ob steno metati.

10.2 Zgodi se tudi, da v članku najdemo zgled, ki spada v drug geselski članek, npr. primer »Trapanci so mu rekali kar stric Mano, saj je padel kot mana z neba" ponazarja v SSF frazem kot z neba pasti, ne pa frazema kot mana $z$ neba; $\mathrm{v}$ članku dati koga/kaj pod lupo najdemo zgled: »Podobno kot pri LDS, ki izgublja politično refleksijo, se dogaja tudi z mediji. Zlasti pri vprašanju, kaj postaviti pod lupo pozornosti«, čeprav najdemo v SSF neglavno iztočnico postaviti koga/kaj pod lupo; prav tako v članku umazano perilo Keber navaja zgled: »Doslej so pranje umazanega perila zaradi kratkih stikov med omenjeno fakulteto in univerzo pometali pod preprogo $[\ldots] \ll, » Z$ a začetek bi se sicer lahko dogovorili, da v javnosti ne bodo prali umazanega perila«, čeprav je v SSF članek prati umazano perilo.

11.1 Še en podatek v SSF je »podatek o nastanku, izvoru, motivu nastanka frazema« (str. 11), kar je precej zapletena naloga, saj zahteva ogromno poznavanja zgodovinskih in kulturnih okoliščin, zunajjezikovnih vplivov, procesov oblikovanja frazemskega pomena idr. Tu si avtor slovarja včasih dovoli precej nestrokovno

${ }^{13}$ Drugi primer (»,Mnogi športniki resda delajo reklamo za brezalkoholne vrste piva, vendar pri tem ne gre za nič več kot figov list,' zajedljivo pripominja Evi Simeoni«) za ponazoritev 1. pomena je naveden napačno, ker tu ne gre ne za umetnost ne za kopalno oblačilo. Ta primer ponazarja drugi pomen frazema. 
razlaganje, možno najbrž le v zelo popularni literaturi. Npr. frazem razbijati si glavo [s čim] ima razlago: »Kot kažejo ustrezni frazemi v drugih jezikih, je bila prvotna sestava frazema verjetno razbijati si glavo ob steno in je bil verjetno povezan s predstavo, da se ob tem razbijanju komu kaj posveti v glavi. To se mu pogosto ne posreči in je tako prizadevanje bob ob steno« (str. 227), kjer je preveč domnev (glede prvotne sestave frazema in glede dopuščanja, da se komu ob razbijanju glave ob steno redkokdaj posveti). Domnevam se da izogniti z navajanjem razlag tujih frazeologov, ki so se ukvarjali s podobnim frazemom v drugih jezikih. Nastanek sorodnega ruskega frazema razbivat'golovu pojasnjuje npr. A. Zoltán: po njegovem mnenju se je ruski frazem pojavil kot kalk nem. sich den Kopf (zer)brechen, ki je nastal iz slovenskega treti si glavo ali iz hrvaškega sorodnega frazema, ki je bil v nemščino preveden napačno, ker imajo v nekaterih primerih slovanski glagoli, kontinuanti praslovanskega *terti, nemško ustreznico brechen, npr. treti lan, konopljo je nem. Hanf, Flachs brechen; ta ustreznica je bila prenesena na slovanski glagol v frazemu treti si glavo. Pri razlaganju frazema Zoltán izhaja iz stereotipne, možne, doživljajske situacije, zato je njegova razlaga verodostojna: »Horvatskij i slovenskij frazeologizmy, v otličije ot nem. sich den Kopf (zer)brechen, imejut jasnyj smysl i daže fiziologičeskoe obosnovanie - stimulirovanije krovoobraščenija mozga posredstvom massirovanija golovy kak naibolee privyčnoe ,vspomogatel'noe sredstvo“ pri usilennom myšlenii« (Zoltán 2006: 140). Na koncu A. Zoltán dodaja, da je frazem nesmiseln, če ga poskusimo razumeti iz pomena njegovih posameznih sestavin, česar navadni govorec običajno ne počne (Zoltán 2006: 141).

11.2 Razlaga nastanka frazema kot rezultata stereotipizacije vsakdanje situacije se upošteva v SSF pri mnogih frazemih, npr. pri hišica iz kart, širiti se kot kuga, kot kura brez glave, siliti z glavo skozi zid idr. Včasih pa se razlaga v SSF zaplete, kot npr. pri frazemu živeti [brez skrbi] kakor vrabec v prosu: »proso kot priljubljena ptičja oziroma vrabčja hrana je postalo prispodoba za blagostanje, dobro počutje«, medtem ko gre za navadno stereotipizacijo. Vendar J. Keber pogosto razlaga nastanek frazema s pomočjo navajanja prenesenih pomenov sestavin frazema. Razlag te vrste je v slovarju veliko, npr.: »Pomen frazema imeti čiste roke temelji na prenesenem pomenu sestavine čist: ki ima pozitivne lastnosti v etičnem, zlasti pa v moralnem pogledu. Sestavina roka je prispodoba delovanja, dejavnosti koga « (str. 822); »Frazem biti v škripcih [...] temelji na sestavini škripci oziroma škripec [...], ki je uporabljena v prenesenem pomenu« (str. 951) idr. V ruskem jezikoslovju se na široko debatira o problemu določanja nastanka frazemov, med drugim tudi o vprašanju t. i. notranje oblike (rus. vnutrennej formy, termin A. Potebnjaja) in nastanka frazema kot določenega postopka, ko se na podlagi izhodiščne (proste) besedne zveze ustvarja slika (scena), ki je podlaga za motivacijo frazemskega pomena. Po mnenju Zimina in Kovalevske, »mehanizm obrazovanija idiom svoditsja v osnovnom k formirovaniju obraza, kotoryj i motivirujet značenije idiom « (Zimin - Kovalevska 2009: 54), zato »mnenije o tom, čto v osnove obrazovanija idiom ležit process pereosmyslenija značenij slov dannoj konstrukciji, javljajetsja krajne obednennym « (Zimin - Kovalevska 2009: 55); to bi lahko rekli o načinu razlaganja frazemov kot skupka prenesenih pomenov sestavin v SSF. 
11.3 Za podatke o nastanku frazema je pomembno zunajjezikovno znanje, še posebej točne informacije o kakšnem dejstvu, ki je postalo izvor za frazem. Tu se splača poiskati informacije in se obrniti na dosežke drugih nacionalnih frazeografij. Npr. v ruskih frazeoloških slovarjih se asfaltovyje džungli s pomenom 'megapolis', ki je ustreznica slov. asfaltni džungli, razlaga kot angleška izposojenka (iz The Asphalt Jungle), ki se je pojavila v ZDA v dvajsetih letih 20. stoletja in je postala znana po knjigi ameriškega pisatelja W. R. Rurnetta (1899-1982) iz leta 1949 in po filmu (iz leta 1950) z enakim naslovom. ${ }^{14}$ Če imamo točen podatek o nastanku frazema - časovno se to ujema s podatki o rabi frazema -, potem je njegov nastanek določen.

S točnimi podatki pa je treba ravnati previdno, ker lahko pride do pomote: npr., J. Keber povezuje nastanek frazema poslednji Mohikanec (mohikanec) (in zadnji Mohikanec) z ameriškim filmom Poslednji Mohikanec (The Last of the Mohicans, ZDA, 1992; The Last of the Mohikans, ZDA, 1936). Zgledi, ki jih navaja Keber, in tudi gradivo slovenskih korpusov priča, da je povezovanje nastanka frazema s filmom iz leta 1992 napačno, ker imajo nekateri primeri rabe frazema letnico 1991 (v GF je 6 takih zgledov). Vendar je možno, da se je frazem pojavil v slovenščini veliko prej, kot je navedeno v SSF. Leta 1926 je bila »povest iz leta 1757 po J. F. Cooper-ju« Zadnji Mohikanec v predelavi A. Benkoviča objavljena v časopisu Slovenski gospodar (Benkovič 1926), Poslednji Mohikanec pa je znan od leta 1900, v Katalogu knjig javne ljudske knjižnice ga najdemo med naslovi knjig za izposojo že od leta 1913 (Katalog 1913: 5); M. Hladnik navaja podatek o Poslednjem Mohikancu iz let 1929-1930 (Hladnik 1983). Zato bi se splačalo poiskati zglede zgodnejše rabe frazema, vsekakor pa bi bilo treba v slovarju navesti podatke o Cooperjevem romanu in njegovih slovenskih prevodih.

11.4 Sistemskost frazeologije ponazarja medsebojna povezanost frazemov, prikazana v SSF. Ugotavljanje vezi med njimi tudi ponuja možnosti za določanje nastanka frazema, tu pa se lahko pojavijo različne razlage. Npr. frazem dajati kaj na brado 'dajati na upanje' ima v SSF razlago: $» V$ navedenih frazemih [pri Kebru dati na brado, na mojo brado - JK] predložna zveza na brado pomeni 'na upanje, na kredit'. V njih brada očitno pars pro toto zamenjuje glavo (prim. zastaviti glavo, življenje za kaj, jamčiti z glavo, življenjem itd.), torej to, kar je vredno zastaviti« (str. 101). Frazem je možno pomensko povezati tudi s frazemoma brada zraste 'zelo dolgo traja', imeti brado 'biti star' ipd., nastanek frazema dajati kaj na brado pa razložiti s predstavo, da se pri prodaji lahko čaka na denar toliko časa, da kupcu zraste brada, torej 'dolgo/nekaj časa'.

Zgoraj (v razdelku 11.1) je bilo omenjeno, da si avtor SSF včasih dovoli poljubnost pri določanju nastanka frazema. To utemeljuje pri opisu nastanka frazema režati se kot pečen maček razlaga: "pečen maček [je] prišel v primero čisto slučajno,

${ }^{14}$ V SSF je nastanek frazema razložen s pomočjo razlage njegovih sestavin: »Pomen frazema asfaltna džungla se je razvil iz prenesenega pomena sestavine džungla: ekspr. 'velika množica' in ekspr. 'tehnično zelo razvita družba, polna notranjih nasprotij'. Sestavina asfaltna določa mesto, prostor tega, kar pomeni sestavina džungla, tj. ceste, ulice velikih mest.« (Str. 194) 
kar je v frazeologiji pogost pojav « (str. 495), medtem ko je naloga frazeologa ravno to, da strokovno prikaže neslučajnost sestave frazema. Razlaga frazema nositi kaj na glavi, ki jo ponuja Keber - »ima kdo breme, težo na glavi, preneseno na možganih, torej tudi na vesti« (str. 223) -, je dvomljiva, ker povezuje možgane in vest, kar ni izpričano v drugih frazemih; bolj logično bi bilo povezati frazem s frazemom imeti maslo na glavi, ker imata frazema sorodna pomena.

11.5 Za frazeme je značilna nazornost, kar je treba upoštevati pri razlaganju frazemov in vezi med njimi. Frazem dajati kaj na brado je nedvomno povezan $\mathrm{s}$ frazemom viseti za brado, in sicer tako, da je slednji nastal po prvem; vendar Kebrova razlaga, da to, kar je na bradi/za brado, »visi nad kom kot neprijetna, nevarna stvar« (str. 101), ni jasna in ni nazorna, saj brada ni nad človekom. Nejasnost je tudi npr. v razlagi frazema moški svojih sanj, »ki naj bi imel sanjske, tj. idealne lastnosti« (str. 548), v frazemu pa gre za moškega, o katerem kdo (ženska) sanja, kar ni enako takemu, ki ima idealne lastnosti. Tudi razlaga, da »[f]razem tla pod nogami gorijo komu temelji na dejstvu, da je treba pred požarom pravočasno zbežati« (str. 975), ne drži, ker v frazemu ni govora o času pred ognjem (požarom), frazem temelji na splošnem znanju, da je ogenj pod nogami nevaren za človeka. Enako je s frazemom iz te moke ne bo kruha, ki ga J. Keber razlaga takole: »Predstava, po kateri je nastal ta frazem, je dovolj razvidna: za peko kruha je potrebna moka, a samo to ne zadostuje, ker ga je treba zamesiti in speči« (str. 545), medtem ko frazem temelji na predstavi, da ni vsaka moka za kruh, tj. moka mora biti določene kakovosti in vrste.

11.6 V slovarju je zaželena strnjena razlaga, v SSF pa na več mestih naletimo na neinformativno gostobesednost, kot npr. pri frazemu biti kot v pravljici: »Primera biti kot v pravljici, pogosto $\mathrm{v}$ obliki je kot v pravljici, temelji na primerjalni sestavini kot $v$ pravljici, ki se nanaša na običajno vsebino pravljic, ki ni vsakdanja, ampak bajna, nenavadna, skratka pravljična« (str. 749). Odveč so v SSF pri razlaganju nastanka slovenskega frazema podatki o pomenu in rabi tujejezičnega frazema, kot npr. pri enoti mi o volku, volk iz gozda: »V poljskem jeziku je klicanje volka iz gozda postalo prispodoba klicanja nesreče in se uporablja navadno zanikano kot svarilo« itd. (str. 1050). Navajanje odvečnih podatkov je najti tudi v drugih člankih, npr. o babilonskem stolpu, kjer se celo izgubi motivacija frazema, ker Keber mimogrede omenja legendo brez razlage, čeprav nadrobno navaja geografske in druge stvarne podatke o stolpu: »Frazem babilonski stolp izhaja iz besedne zveze babilonski stolp 'po bibliji stolp, ki naj bi segal do neba'. Sicer pa je bil babilonski stopničast stolp v Mardukovem svetišču na zahodu Babilona. Njegova osnovna stranica je merila več kot $2000 \mathrm{~m}^{2}$, visok pa je bil $90 \mathrm{~m}$. Stopničast stolp - zigurat - naj bi predstavljal pot, ki povezuje nebo in zemljo. Nanj se zato navezuje veliko mitov in pripovedk, med njimi o babilonski zmešnjavi jezikov. Iz slednje verjetno tudi izhaja današnji pomen frazema babilonski stolp.« (Str. 915)

Sestavine, potrebne za razumevanje frazema, se včasih izgubijo med nepotrebnimi podatki, kot npr. pri frazemu hoditi od Poncija do Pilata, kjer je govor o češkem in poljskem frazemu (str. 727), ni pa opozorila, da gre v slovenskem frazemu za hojo med dvema imenoma istega človeka, kar krepi pomen nesmiselnosti početja. 
12.1 Zadnje, na kar bi si želela opozoriti, so vzporednice iz drugih jezikov, in sicer iz ruščine. Pri pripravljanju SSF za tisk ni bilo pregleda ruskih ustreznikov, čeprav je bilo gradivo iz drugih jezikov pregledano (str. 2). Najbrž je zato prišlo poleg dobro izbranih ruskih ustreznic (npr. vrabci na strehi že čivkajo [o čem], rus. ob ètom uže vse soroki treščat; tepsti koga kakor vola, rus. otodrat'/drat'kak sidorovu kozu idr.) do številnih napak pri navajanju ruskih vzporednic. Naj navedem nekaj primerov:

- za postaviti na glavo 'zelo, temeljito se spremeniti' je naveden rus. otbivat'sja rukami i nogami, ki pomeni 'močno nasprotovati čemu, kar se ponuja'; bolje bi bilo perevernut's nog na golovu;

- za odjektniti kot bomba 'zelo odmevati, vzbujati veliko presenečenje' je navedeno rus. lopnut' kak bomba, ki ima pomen 'zaman, brez uspeha'; prva navedena ustreznica pa je pravilna;

- po toči zvoniti 'prepozno začeti delovati, ukrepati' ima v ruščini ustrezni frazem posle draki kulakami mahat', naveden pa je prijti k šapočnomu razboru 'priti prepozno, ko se je vse končalo' (SRF);

- za biti ad acta je navedeno rus. položit'v dolgij jaščik 'odlagati izvršitev kakšne naloge za nedoločen čas' (FSRJ);

- pri frazemu priti na boben je navedeno rus. vyletet'v trubu in okazat'sja na meli, zadnji ruski frazem ima pomen 'znajti se v težkem položaju' (SRF);

- imeti cmok v grlu ima formalno in pomensko rusko ustreznico komokv gorle, v SSF napačno kaša vo rtu 'kdo govori nerazločno, nejasno' (SRF);

- za imeti svetle trenutke 'biti občasno zelo uspešen, srečen' je navedeno rus. $u$ kogo byvajut minuty projasnenija,${ }^{15}$ česar npr. ne najdemo v ruskem korpusu, zelo pogost pa je v ruščini frazem svetlyje minuty, ki formalno in pomensko ustreza slovenskemu;

- držati koga na kratko 'imeti koga popolnoma v oblasti' - rus. deržat'na korotkom povodke, v SSF navedeni frazem deržat'v ježovyh rukavicah pomeni 'ravnati preveč strogo s kom';

- pri imeti [dolg, tak] jezik kot krava rep 'biti zelo zgovoren, čvekav' je namesto ustreznega rus. jazyk kak pomelo, jazykom molot'navedeno jazyk kak britva u kogo, ki pomeni 'biti odrezav, napadalen';

- vreči koga na finto 'prevarati koga' je navedeno rus. vykinut'fint, ki ima pomen 'narediti nekaj nepričakovanega, nesprejemljivega' ('soveršit' neožidannyj predosuditeljnyj postupok' (FSRJ)) namesto ustreznejših rus. obvesti vokrug paljca ali natjanut'nos;

- primera kot nevesta ima v slovenščini pozitivne konotacije: 'lep, lepo oblečen človek', navedena ruska ustreznica vyrjadit'sja kak na svad'bu pa ima negativne.

15 To frazo bi lahko razumeli v zvezi s trenutnim olajšanjem psihične bolezni. 
12.2 Pri navajanju tujejezičnih ustreznic slovenskih večpomenskih frazemov je pomembno, h kateremu pomenu je navedena vzporednica; npr. frazem $i z$ polnih pljuč ima v SSF navedeno rus. ustreznico vo vsë gorlo, kar je prav, če gre za prvi pomen slovenskega frazema, 'zelo glasno', medtem ko naj bi bila ruska ustreznica za drugi pomen, ki je določen v SSF kot 'iz vseh moči', sodeč po zgledih 'polnoj grudju'.

12.3 V ruskih zgledih so tudi tiskarske, skladenjske napake, kot npr. slyšet'> slyšat', povernut'sja kak bumerang > vernut'sja kak bumerang, golova zabyta $>z a-$ bita, byt'ot togo že testa $>$ byt' iz togo že testa idr.

13.1 Ne glede na vse naštete pomanjkljivosti in nedoslednosti je izid Slovarja slovenskih frazemov velik napredek v razvoju slovenske frazeografije, ker je zbirka frazemov in njihovih različic $\mathrm{v} \mathrm{SSF}^{16}$ dovolj velika v primerjavi z dosedanjimi zbirkami slovenskih frazemov; slovar vsebuje zanimive podatke o izvoru, času nastanka slovenskih frazemov itd. Po drugi strani pa je videti, da je avtor precej nedosleden v izvajanju izdelane zasnove. Premalo oprijemljiva so merila za oznake, niso določena teoretska izhodišča za ugotavljanje in obravnavo pomenov, za razlago nastanka frazemov. Zapleten sistem kazalk, grafično neizrazite glavne iztočnice, navajanje frazeoloških različic ne pomaga k optimalni ureditvi frazeološkega gradiva. Avtor piše, da je SSF namenjen širokemu krogu bralcev, vendar se zdi, da morajo biti tudi za takega bralca podatki v slovarju znanstveno kar se da zanesljivi, verodostojni in utemeljeni.

${ }^{16}$ Za vsak slovar je pomemben podatek o številu zajetih enot. V predgovoru J. Keber piše: »Za boljšo orientacijo pri določanju števila frazemov, obdelanih v frazeološkem slovarju, sem primerjal tudi število frazemov v nekaterih frazeoloških slovarjih drugih jezikov. Število obdelanih frazemov in čas izdelave frazeološkega slovarja v zasnovi sta bila zaradi kompleksnosti seveda lahko samo približna (pet let in 10.000 frazemov), dejansko pa je število po konceptu obdelanih frazemov v času 8 let več kot 5000. To je - resda samo obsegovno, ne pa konceptualno - primerljivo z nekaterimi sodobnejšimi frazeološkimi slovarji« (str. 13). Za zglede tujejezičnih slovarjev J. Keber navaja poljski frazeološki slovar (Głowińska 2000; 5000 enot), ruskega (Birih idr. 2005; 6000 enot), lužiškega (Ivčenko - Wölke 2004; 3600 enot). Ker iz navedenega ni jasno, koliko enot vsebuje SSF, sem poskusila ugotoviti okvirno število enot tako, da sem preštela, koliko frazemov vsebuje trikrat po 50 strani: str. 50-100 - 108 frazemov, str. $450-500-123$, str. $750-800-105$, torej na vsakih 100 strani od 210 do 246 frazemov, skupaj na 1123 straneh 2500-2600 frazemov. Seštevanje frazemov je seveda odvisno od odgovora na vprašanje, ali so pari in trojčki, ki se razlikujejo oblikoslovno, komponentno, besedotvorno ali leksikalno en frazem ali so različni frazemi (kot npr. vsake bire in baže in vsake bire; bogu za hrbtom, biti bogu za hrbtom in živeti bogu za hrbtom; ob kruhu in vodi in živeti ob kruhu in vodi; izvleči koga/kaj iz blata in izvleči se iz blata; topli brat in topli bratec; tiho kot v cerkvi in tišina kot v cerkvi; cmok v grlu, cmok v grlu se naredi komu, imeti cmok v grlu; biti v [veliki časti] in biti v velikih časteh; modra kri, biti modre krvi in imeti modro kri; biti starega kova in starega kova; pometanje pod preprogo in pomesti pod preprogo, pometati pod preprogo; biti po jusu in ne biti po jusu itd.). 
Benkovič 1926=Alojzij Benkovič,Zadnji Mohikanec, Slovenskigospodar60(1926), št. 33 (19. 8.) 〈http://www.dlib.si/?URN=URN:NBN:SI:DOC-01U8QR0G〉.

Fjodorov $1973=$ A. I. Fedorov, Razvitie russkoj frazeologii v konce XVIII-načale XIX veka, Novosibirsk: Nauka, 1973

Hladnik 1983 = Miran Hladnik, Trivialna literatura, Ljubljana: DZS, 1983 (Literarni leksikon 21). 〈http://lit.ijs.si/trivlit1.html〉

Katalog 1913 = Katalog knjig javne ljudske knjižnice »Gospodarskega in izobraževalnega društva za dvorski okraj« v Ljubljani, Ljubljana: Gospodarsko in izobraževalno društvo za dvorski okraj, 1913 〈http://www.dlib. si/?URN=URN:NBN:SI:DOC-YWVKNRRQ $\rangle$.

Keber 2003 = Janez Keber, Frazeološki slovar slovenskega jezika: poskusni zvezek, Ljubljana: Založba ZRC, ZRC SAZU, 2003.

Kržišnik 1987/88 = Erika Kržišnik, Frazeološko gradivo v Slovarju slovenskega knjižnega jezika, Slava 2 (1987/88), št. 2, Ljubljana, 143-162.

Kržišnik 2004 = Erika Kržišnik, Poskusni zvezek slovenskega frazeološkega slovarja, Slavistična revija 52 (2004), št. 2, 199-208.

Mokijenko 1989 = V. M. Mokienko, Slavjanskaja frazeologija: učebnoe posobie dlja vuzov, Moskva: Vysšaja škola, ${ }^{2} 1989$.

Petermann 1988 = Jürgen Petermann, Frazeologija v slovarju slovenskega knjižnega jezika (I-IV): nekaj osnovnih vprašanj o vlogi frazeologije v slovarju, v: Sodobni slovenski jezik, književnost in kultura, Ljubljana: Filozofska fakulteta 1988 (Obdobja 8), 301-310.

Rojs 2012 = Jurij Rojs, Kebrov Slovar slovenskih frazemov, Jezikoslovni zapiski 18 (2012), št. 1, 209-212.

Vostrecova $2009=\mathrm{V}$. A. Vostrecova, K probleme variativnosti frazeologičeskih edinic, v: Frazeologizm v tekste in tekst vo frazeologizme: četvertye Žukovskie čtenija: materialy meždunarodnogo naučnogo simpoziuma, Velikij Novgorod: NovGU im. Jaroslava Mudrogo, 2009, 39.

Zimin - Kovalevska 2009 = V. I. Zimin - L. A. Kovalevskaja, Ujasnenie mehanizmov idiomoobrazovanija, v: Frazeologizm v tekste in tekst vo frazeologizme: četvertye Žukovskie čtenija: materialy meždunarodnogo naučnogo simpoziu$m a$, Velikij Novgorod: NovGU im. Jaroslava Mudrogo, 2009, 55-57.

Zoltán 2006 = András Zoltán, Frazeologizm lomat'golovu v sravnitel'nom aspekte (po povodu vyhoda novogo izdanija knigi »Russkaja frazeologija: istoriko-ètimologičeskij slovar'« pod red. V. M. Mokienko), v: Russkaja, ukrainskaja i rusinskaja leksikologija i leksikografija: sbornik statej pamjati professora Ištvana Udvari, ur. Erszébet Cs. Jónás, Nyíregyháza: Krúdy Könyvkiadó, 2006, 133-143.

Žukov 1978 = V. P. Žukov, Semantika frazeologičeskih oborotov: učebnoe posobie dlja studentov filolog. special'nostej vuzov, Moskva: Prosveščenie, 1978. 


\section{Slovarji}

Bojc 1987 = Etbin Bojc, Pregovori in reki na Slovenskem, Ljubljana: DZS, 1987. FSRLJ = A. Fedorov, Frazeologičeskij slovar' russkogo literaturnogo jazyka, Moskva: Astrel' AST, 2008 〈http://phraseology.academic.ru〉.

FSSJ PS = Janez Keber, Frazeološki slovar slovenskega jezika: poskusni zvezek, Ljubljana: ZRC SAZU, 2003.

Pavlica 1960 = Josip Pavlica, Frazeološki slovar v petih jezikih, Ljubljana: DZS, 1960.

$\mathrm{SF}=$ Stownik frazeologiczny - stownik jezykowy $\langle\mathrm{http}: / / \mathrm{www} \cdot$ sciaga.pl $\rangle$.

SFSRJ = V. P. Žukov - M. I. Sidorenko - V. T. Škljarov, Slovar'frazeologičeskih sinonimov russkogo jazyka, Moskva: Russkij jazyk, 1987.

Skorupka 1967 = Stanisław Skorupka, Stownik frazeologiczny języka polskiego 1, Warszawa: Wiedza powszechna, 1967.

Smiešková 1983 = Elena Smiešková, Malý frazeologický slovník, Bratislava: Slovenské pedagogické nakladatel'stvo, ${ }^{3} 1983$.

$\mathrm{SRF}=\mathrm{A} . \mathrm{K}$. Birih - V. M. Mokienko - L. I. Stepanova, Slovar'russkoj frazeologii: istoriko-ètimologičeskij spravočnik, S.-Peterburg: Folio-Press, 2005.

SSKJ = Slovar slovenskega knjižnega jezika 1-5, Ljubljana: SAZU oz. ZRC SAZU (izd.) - DZS (zal.), 1970-1991.

BFSRJ = V. N. Telija, Bol'šoj frazeologičeskij slovar' russkogo jazyka, Moskva: Ast-press kniga, 2006.

TSFSRJ = V. P. Žukov - M. I. Sidorenko - V. T. Škljarov, Tolkovyj slovar'frazeologičeskih sinonimov russkogo jazyka, Moskva: Astrel', 2005.

$\mathrm{KSBF}=\mathrm{L}$. G. Kočedykov - L. V. Žil'cova, Kratkij slovar' biblejskih frazeologizmov 〈http://www.bible-center.ru/dict/phrases $\rangle$.

\section{Vira}

$\mathrm{GF}=$ Gigafida: korpus slovenskega jezika (projekt Sporazumevanje v slovenskem jeziku) $\langle\mathrm{http}: / /$ demo.gigafida.net $/\rangle$.

$\mathrm{Nb}=$ Besedilni korpus Nova beseda $\langle$ http://bos.zrc-sazu.si/s_beseda.html $\rangle$. 